\title{
An Australian and New Zealand scoping study on the use of 3D immersive virtual worlds in higher education
}

\author{
Barney Dalgarno, Mark J. W. Lee, Lauren Carlson \\ Charles Sturt University \\ Sue Gregory and Belinda Tynan \\ University of New England
}

\author{
An Outstanding Paper Award recipient, ascilite Sydney 2010 Conference
}

\begin{abstract}
This article describes the research design of, and reports selected findings from, a scoping study aimed at examining current and planned applications of 3D immersive virtual worlds at higher education institutions across Australia and New Zealand. The scoping study is the first of its kind in the region, intended to parallel and complement a number of studies conducted in other parts of the world. Results from a sector-wide questionnaire administered as part of the scoping study, portions of which are presented in this article, appear consistent with international trends, especially in terms of the platforms chosen and the dramatic increase in usage seen in recent years. Higher education teaching staff in Australia and New Zealand are using 3D immersive virtual worlds with their students in a variety of ways, for both assessable and non-assessable tasks and in face to face, fully online/distance as well as blendedmode subjects, although use in face to face and blended contexts appears to be most common. The results also provide some insight into the demographics (e.g. age) of staff who have adopted 3D immersive virtual worlds in their teaching, as well as into the academic disciplines in which the technology is being employed.
\end{abstract}

\section{Introduction}

Much attention and interest are being given to 3D immersive virtual worlds such as Second Life and Active Worlds and their potential for supporting and enhancing tertiary learning, teaching and pedagogy. Academics from two Australian universities, Charles Sturt University (CSU) and the University of New England (UNE), are working currently on a project to conduct a systematic review and environmental analysis of the use of 3D immersive virtual worlds in higher education in Australia and New Zealand. This work is parallel and complementary to other similar, sector-level research completed in other countries. The project seeks to identify and examine existing applications of 3D immersive virtual worlds by higher educators throughout Australia and New Zealand, with the aim of developing an understanding of how the technology is being used for learning and teaching across institutions and disciplines. The project will also report on the views and perceptions of higher educators who are not yet using 3D immersive virtual worlds in their teaching, but are actively exploring the possibilities, as well as the experiences of those who have previously considered this avenue, but have chosen not to pursue it or been otherwise unable to do so.

The study is being carried out under the auspices of the Distance Education Hub (DEHub at http:/ / www.dehub.edu.au/), a federally funded research consortium based at UNE, that involves UNE, CSU, Central Queensland University (CQU) and the 
University of Southern Queensland (USQ) in Australia, and Massey University in New Zealand. In late 2009, DEHub established a Virtual Worlds Working Group (VWWG) to assist in facilitating cross-institutional collaborative research into educational uses of 3D immersive virtual worlds. The VWWG strives to identify research gaps and to define, document and promote good and/or best practices in this area. The scoping study project will provide the VWWG, as well as ascilite and the educational technology and higher education communities at large, with exemplars, guidelines and recommendations to encourage the successful uptake, implementation and use of 3D immersive virtual worlds by educators, institutions and their students.

The timeliness of a scoping study with this Australian and New Zealand focus is demonstrated in the coverage of 3D virtual worlds and multi-user virtual environments seen at the 2009 ascilite Conference, where there were no less than 13 sessions and posters relating to this topic. The papers in the published Proceedings (Atkinson \& McBeath, 2009) collectively illustrate the diversity of research and practice in the use of the technology in Australian and New Zealand higher education. For example, within this collection of papers there are reports of applications in a wide range of disciplines including teacher education (Campbell, 2009), nurse education (Rogers, 2009) and cultural studies (Henderson, Huang, Grant \& Henderson, 2009), plus research studies with a wide range of foci including educator perceptions (Gamage, Tretiakov \& Crump, 2009), student perceptions (Gregory \& Tynan, 2009) and virtual world teaching practices (Willems, 2009). Similarly, at the 2010 ascilite Conference, one workshop, two dedicated symposia and a total of 12 additional papers and posters were presented in this area (see the Conference Proceedings - Steel, Keppell, Gerbic \& Housego, 2010). Particularly noteworthy is a paper co-authored by 23 members of the DEHub VWWG from 17 different Australian institutions, showcasing what they have been doing in this nascent field (Gregory et al., 2010).

This article begins with an overview of the key extant literature, before describing the background and overall motivations for the scoping study project. It then details the study, including its aims and objectives, research design/methodology, and dissemination methods. Next, selected results and findings from the sector-wide questionnaire are reported. Finally, the article concludes with a discussion of emergent themes from the results and an outline of the project team's plans for the remainder of the study.

\title{
Key literature, background and rationale for the study
}

The working definition of a '3D immersive virtual world' adopted for the purposes of the project is that proposed by Lee (2010, p. 2):

\begin{abstract}
a computer-based, simulated environment in which users are able to immerse themselves, and within which they are able to, through their avatars (computer-based representations of themselves or alternative selves), experience, manipulate, interact with and/or create virtual objects and places that are graphically depicted in three dimensions. The objects and places within a virtual world may be modelled according to those in the real world or may be fantasy based. Most current virtual world applications allow for multiple users and include facilities that enable users to communicate and interact with one another within the virtual environment.
\end{abstract}

In the United States, the 2007 Horizon Report (New Media Consortium, 2007) classified virtual worlds as an emerging area likely to impact higher education within the next two to three years. In the following year, the inaugural edition of the Australia-New Zealand version of the Horizon Report (Johnson, Levine \& Smith, 2008) was released. It 
pinpointed 'virtual worlds and other immersive digital environments' as a 'technology to watch' with a likely time to adoption of one year or less. In a recent review of empirical research covering both K-12 and higher education settings internationally, Hew and Cheung (2010) found that 3D immersive virtual worlds were being used for three main purposes: (i) as communication spaces, (ii) for simulation of space (spatial), and (iii) as experiential spaces ('acting' on the world). Lee (2009) analysed cases of 3D immersive virtual world use in education, with an emphasis on the collaborative aspects of the facilitated learning activities. In addition to the powerful affordances of the technology and the rich possibilities it offers for enhancing and enriching the student learning experience, higher education is faced with an imperative in that, as argued by Collins (2008), it "has a significant role to play ... [as] Business and industry will be looking for an educated workforce ready to meet the challenges these new environments present, from new modes of marketing, design, and manufacturing to new kinds of management and organizational leadership models that leverage virtual environments as one option in a suite of online tools serving the needs of companies and their customers" (p. 56).

The Joint Information Systems Committee (JISC at http://www.jisc.ac.uk/) in the UK has already commissioned a scoping study on serious virtual worlds in the British education and training industry, and published a report of its findings (de Freitas, 2008). This report includes a thorough review of the field, plus case study examples that are representative of the multitude of ways in which 3D immersive virtual worlds can be and are being used for learning, including but not limited to mentoring, constructionist activities, exploratory trails and quests, role plays and skill practice. According to the report, virtual worlds also have the potential to support a range of cross-disciplinary collaborative research and learning opportunities that are only starting to emerge. Additionally, the JISC report provides valuable resources for researchers and practitioners, such as a typology and a list of virtual worlds.

Also in the UK, Kirriemuir (2007a, 2007b, 2008a, 2008b, 2009a, 2009b, 2009c, 2010) authored a series of eight rolling 'snapshots' of the use of 3D immersive virtual worlds in higher education and further (i.e. vocational) education over a three-year period. This work was funded and supported by Eduserv (http://www.eduserv.org.uk/). Like the JISC report, the Eduserv snapshot reports testify to rapid growth in the number of UK academics using 3D immersive virtual worlds - by Spring 2009, there was evidence of almost every university in the nation using the technology in some way for development and/or teaching (Kirriemuir, 2009b). A large proportion of the activities and initiatives have been funded internally, with staff frequently donating considerable amounts of their own time. As with the JISC study, academics surveyed by Kirriemuir made reference to a broad spectrum of 3D immersive virtual worldbased activities spanning the domains of learning, teaching, research, performance, demonstration and construction. A vast array of application types and subject areas of use are represented in the snapshot reports, but the more recent reports point to the emergence of some clear trends. For example, the health and medical science disciplines account for a large proportion of 3D immersive virtual world activity in UK academia, although others such as languages, computer science, health and safety, and art, performance and design also stand out as areas in which many institutions are using the technology for learning and teaching (Kirriemuir, 2009a, 2009c).

The EDUCAUSE Center for Applied Research (ECAR at http://www. educause.edu/ecar/) in the USA has also issued a research bulletin on Second Life in education, focussing primarily on the tertiary sector (Kelton, 2007). This bulletin draws on recent literature, as well as interviews with several educators and innovators, to 
provide coverage of both technological and pedagogical aspects of the technology's use. Similar to the UK reports mentioned above, the content of the ECAR bulletin, especially the examples included of how academics are using Second Life as a training, teaching and research tool, speaks to the vast range of applications that are possible. Indeed, the author of the bulletin observes that "it seems as if each institution is using this tool in a way that reflects of its own perceived need" (p. 5). He goes on to comment that "being able to state with any certainty what most or many institutions are doing is difficult at best ... [which] is further complicated by the fact that in some instances it is one individual, department, or even academic unit that constitutes the institution's presence" (p. 5).

In Australia, Bradshaw (2006), in her report for the Australian Flexible Learning Framework (http:/ / www.flexiblelearning.net.au/), looked at virtual world use in the VET (vocational education and training) sector, where she found that virtual worlds had the potential to be used in ways that are engaging for students, encouraging creativity, learning through simulations, experimentation and observation while promoting increased immediacy, expanded horizons and the building of selfawareness. There is a need for research that is parallel and complementary to the above and concentrates on the Australian and New Zealand higher education perspective. Such research should transcend isolated 'show and tell' and anecdotal reports to accurately depict and represent in detail the unique opportunities, challenges and realities of the technology and its deployment and use within the highly dynamic, evolving national higher education context in these two countries.

The DEHub scoping study project is intended to address this need, culminating in the provision of analysis and recommendations to inform policy, practice and future research in the field. It is particularly significant for a number of reasons. Firstly, no Australian or New Zealand study of its kind has been undertaken to date, and there has been no national capture of activities, uses and impact of 3D immersive virtual worlds for enhancing higher education learning and teaching in either country. Secondly, there is a need for an accurate picture of the 'state of play', including current, past and planned applications at the various institutions, so as to help direct future research, development and use. Thirdly, the compilation of an annotated bibliography of published research into, and evaluations of, 3D immersive virtual worlds in Australian and New Zealand higher education will provide a solid platform for further research. Last but not least, an examination of the lessons learnt, including perceived and actual costs and benefits, support provided and barriers to use of the technology at the various institutions, will be invaluable in informing future applications and initiatives.

\section{Details of the study}

\section{Aims and objectives}

The scoping study primarily seeks to achieve a broad understanding of the current 'state of play' or 'lie of the land' of 3D immersive virtual worlds in the Australian and New Zealand higher education environment. There is particular emphasis in the study on university teachers', educational designers' and information technology (IT) support staff members' perceptions and experiences relating to the use of the technology for learning and teaching. Specifically, the objectives of the study are to:

- Compile a list of higher education practitioners who have explored the use of 3D immersive virtual worlds in their teaching; 
- Locate and document a range of examples of current, past or planned 3D immersive virtual worlds use at the various institutions for learning and teaching purposes;

- Examine the costs and perceived benefits for learning and teaching (as well as the actual benefits, where these have been evaluated);

- Collate an annotated bibliography;

- Identify the current level(s) of access to and support for 3D immersive virtual worlds afforded by the institutions to their students and staff, as well as any training provided in their use; and

- Provide a forum for collating and disseminating lessons learnt by academics and institutions, both individually and collectively.

A secondary goal of the study is to isolate actual and perceived barriers to adoption, uptake and use of the technology within institutions, and to assemble and disseminate advice on how academics and institutions can effectively overcome such barriers.

Overall, the project strives to assist in facilitating ongoing dialogue and exchange of ideas within a community of researchers and practitioners among institutions involved in DEHub as well as in the educational technology and higher education communities more broadly.

\section{Research design/methodology}

The scoping study consists of three phases of data collection:

1. Literature searches and searches of institutional web sites for the purpose of compiling an initial database of higher education staff who have a known interest or involvement in using 3D immersive virtual worlds for learning and teaching;

2. An online questionnaire to elicit detailed information about the ways in which $3 \mathrm{D}$ immersive virtual worlds have been/are being used, and the perspectives of the teaching staff involved; and

3. Interviews to gather more detailed information and perspectives from a subset of questionnaire respondents.

Phase 1: Compilation of a 3D immersive virtual world user database (January 2010 to May 2010)

A database of 179 higher education staff members who use, have used or have considered using 3D immersive virtual worlds in their teaching was compiled through literature searches, web searches and word of mouth networking. This database provided a list of potential respondents to the questionnaire. The 179 individuals identified included 94 males and 87 females, with 135 of them based at Australian institutions and the other 44 based at New Zealand institutions.

Phase 2: Questionnaire (February 2010 to August 2010)

The questionnaire was developed using an iterative process, with initial drafts generated through discussions within the project team, followed by the trialling of key questions with potential participants using cognitive interviewing techniques (see, for example, Willis, 1999). A pilot version of the questionnaire was then produced using the SurveyMonkey (http://www.surveymonkey.com/) online questionnaire delivery platform and tested with the help of 10 participants, including members of the DEHub VWWG as well as other identified individuals with appropriate expertise. A final version of the questionnaire was created based on feedback from this group. 
The questionnaire included questions arranged into the following sections:

1. Demographic data including age, gender, institution, teaching discipline area, teaching experience and experience with 3D immersive virtual world platforms;

2. Views and beliefs about the potential of $3 \mathrm{D}$ immersive virtual worlds for learning and teaching;

3. Summary information about each subject in which 3D immersive virtual worlds had been used including the years of offering, the discipline area, the virtual world platform used, the delivery mode, the number of students involved, whether the use of virtual worlds was compulsory and whether it was an assessable component of the subject;

4. More detailed information about a single subject in which 3D immersive virtual worlds were used; and

5. Key success factors and barriers to the use of 3D immersive virtual worlds in learning and teaching as perceived by participants, based on their observations and experiences.

Besides approaching individuals directly via email to invite them to participate, the questionnaire was made available through various electronic mailing lists/listservs and other distribution mechanisms. In particular, the questionnaire was publicised through the listservs and newsletters or bulletins of several associations, including ascilite (Australasian Society for Computers in Learning in Tertiary Education), the Open and Distance Learning Association of Australia (ODLAA), the Higher Education Research and Development Society of Australasia (HERDSA) and the Distance Education Association of New Zealand (DEANZ). Similar announcements were distributed to a number of national and international online communities with a specific interest in the use of 3D immersive virtual worlds in education, such as SLED (the Second Life Educators group) and AusSLERs (Australian Second Life Educators and Researchers). As an incentive, those completing the questionnaire were able to opt to be placed in a draw for a chance to win their choice of either an 8GB iPod touch or Au\$250 paid as Linden Dollars (the currency used in Second Life).

The questionnaire was kept online and open to accept responses for a period of eight weeks between June and August 2010. Analysis of the quantitative data to date has been primarily descriptive to paint a picture of the scope of applications of 3D immersive virtual worlds across the two countries; however, some inferential statistics will be employed at a later stage in order to provide clarity when comparing the responses of various subgroups within the respondent population.

Phase 3: Interviews (August 2010 to March 2011)

From the list of questionnaire respondents, up to 36 people will be approached to be individually interviewed. Pilot testing of the interview questions, procedures and protocols is in progress at the time of writing of this article. The interviews are scheduled to take place between January and March 2011, and will be semi-structured, each lasting 30 to 45 minutes. Interviewees will be asked to elaborate on their views, experiences, observations and reflections in relation to the use of 3D immersive virtual worlds for learning and teaching as described in their questionnaire responses. They will also be encouraged and given the opportunity to discuss in detail the ways in which they have used and/or intend to use the technology in their teaching practice, along with the motivating factors and pedagogical drivers underlying their instructional designs and decisions. It is anticipated that a cross section of participants from a range of institutions, including academics from various discipline groups, as well as educational designers and IT support staff, will be interviewed. Some 
interviewees may also be given the opportunity to work with the project team to write up their experiences in using 3D immersive virtual worlds as case studies for inclusion in the final report for the project.

\section{Dissemination}

The outcomes of the scoping study will be published as a report to be made accessible via the DEHub web site. On top of reporting on the data collected during each of the three phases of data collection, the report will also include a comprehensive annotated bibliography of publications about the use of 3D immersive virtual worlds in higher education in Australia and New Zealand. Additionally, key findings will be shared with the educational technology and higher education communities through delivery of conference presentations and production of journal articles and/ or book chapters.

\section{Results}

The results presented below provide a valuable snapshot of 3D immersive virtual world use in higher education in Australia and New Zealand. The data chosen for reporting in this article are drawn from sections 1 and 3 of the questionnaire (as described above), that is, demographic data about the respondents and summary data about the particular subjects in which 3D immersive virtual worlds have been used. Data from the other sections of the questionnaire will be published in the final project report.

\section{Demographic information about initial respondents}

The 117 respondents to the questionnaire included 59 males, 56 females, and 2 who did not specify their gender. There were 9 people in the 26-35 years age range, 40 in the $36-$ 45 years age range, 46 in the 46-55 years age range, 19 in the 56-65 years age range, 1 in the over 65 years age range, and again 2 who did not specify. This is interesting because it supports, at least to some degree, the findings of researchers such as Kennedy et al. (2009), who argue that contrary to assertions by some commentators on 'digital natives' (Prensky, 2001a, 2001b) and the 'Net Generation' (Oblinger \& Oblinger, 2005), younger academics are not in fact more likely than older academics to use new technologies in their teaching. However, these results may need to be considered in light of differences in the opportunities available to academics of different levels of seniority. For example, junior academics may have less autonomy in subject and course design, and less access to funding and support for technology and innovation projects.

The respondents included 82 from Australia and 35 from New Zealand. A total of 62 respondents indicated that they had actually used 3D immersive virtual worlds in their own teaching.

\section{D immersive virtual world usage trends}

The 62 respondents who indicated they had used 3D immersive virtual worlds in their teaching reported on a total of 125 individual subjects in which they had used the technology, including 201 individual subject offerings. Figure 1 shows the distribution of these subject offerings over the past 10 years. There is a definite upward trend in usage, with offerings in 2008 (44) being well over double the number in 2007 (18), offerings in 2009 (56) increasing substantially again, and offerings in the first half of 2010 (51) already approaching those over the whole of 2009. 


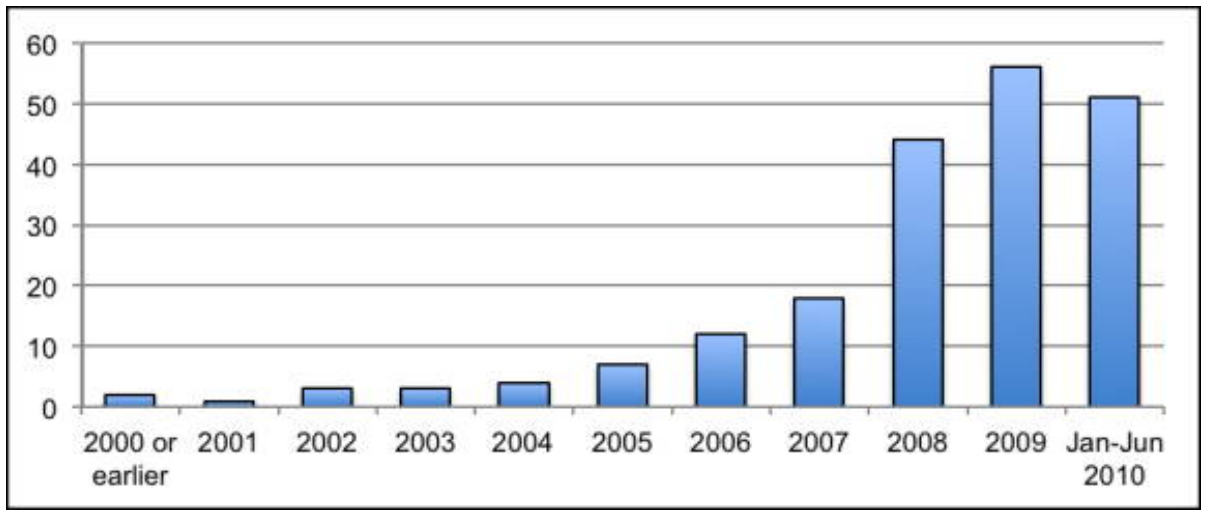

Figure 1: Distribution of subject offerings in which 3D immersive virtual worlds have been used over the past 10 years

\section{D immersive virtual world platforms}

Of the 62 respondents who indicated that they had used 3D immersive virtual worlds in their teaching, 61 provided data on the particulars of a total of 100 subjects, about which summary information is presented in this subsection and the next three subsections.

Figure 2 shows the 100 subjects, broken down by virtual world platform. As expected, the vast majority of subjects using 3D immersive virtual worlds employed Second Life (78.0\%), with Active Worlds (5.0\%) being the next most commonly used platform, followed by OpenSim (4.0\%) and There.com (1.0\%). Vastpark, Multiverse, Worlds.com, Reaction Grid and web.alive were listed on the questionnaire but were not chosen by any respondents. The remaining respondents $(12.0 \%)$ indicated that they had used another, unlisted platform. Of these respondents, one specified that he had used the MaidMarian MMORPG (massively multiplayer online role-playing game). Others reported using worlds developed using the Neverwinter Nights toolset, the Torque game engine, the Unreal Tournament game engine, OpenGL, Blender and the Virtual Reality Modeling Language (VRML).

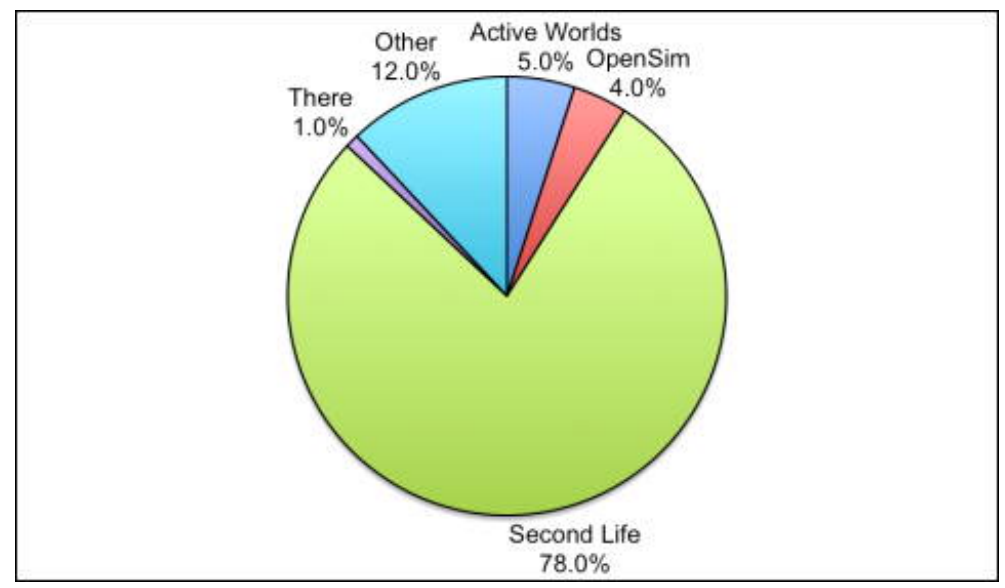

Figure 2: 3D immersive virtual world usage by platform 


\section{Delivery mode}

Figure 3 shows the 100 subjects broken down according to delivery mode. The majority of subjects reported to have made use of 3D immersive virtual worlds were delivered in face to face mode $(60.0 \%)$, which may be reflective of the fact that a larger proportion of subjects across the sector are delivered in this mode. Alternatively, these results may signal that the use of 3D immersive virtual worlds requires levels of instructional and technical support that make them difficult to use in non-face to face teaching.

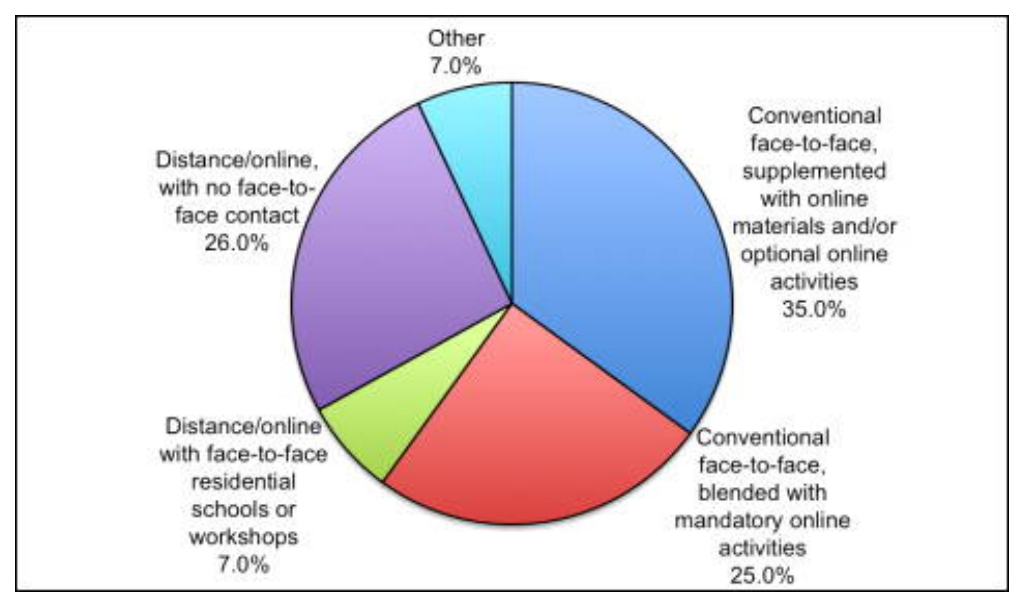

Figure 3: Subjects using 3D immersive virtual worlds by delivery mode

\section{Role of 3D immersive virtual world tasks: Assessed and/or compulsory}

Figure 4 shows the proportion of the 100 subjects where the virtual world-based tasks were (i) compulsory and assessed (41.0\%); (ii) compulsory and not assessed (16.0\%); or (iii) neither compulsory nor assessed $(43.0 \%)$. The large number of subjects in which the offerings were neither compulsory nor assessed arguably implies that the use of 3D immersive virtual worlds is not yet a mainstream or core part of many subjects.

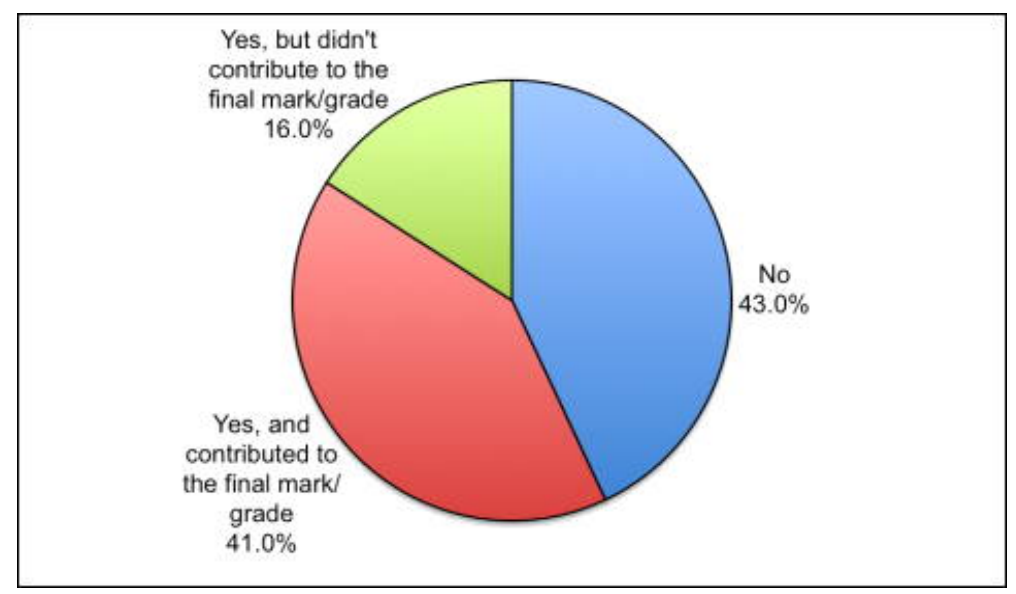

Figure 4: Subjects using 3D immersive virtual worlds by role of virtual world tasks 


\section{Subject level and discipline}

Figure 5 shows the 100 subjects broken down by level of study. The data appear to suggest that they are being used predominantly with undergraduate students. This could, of course, simply be because there are more students enrolled in undergraduate courses.

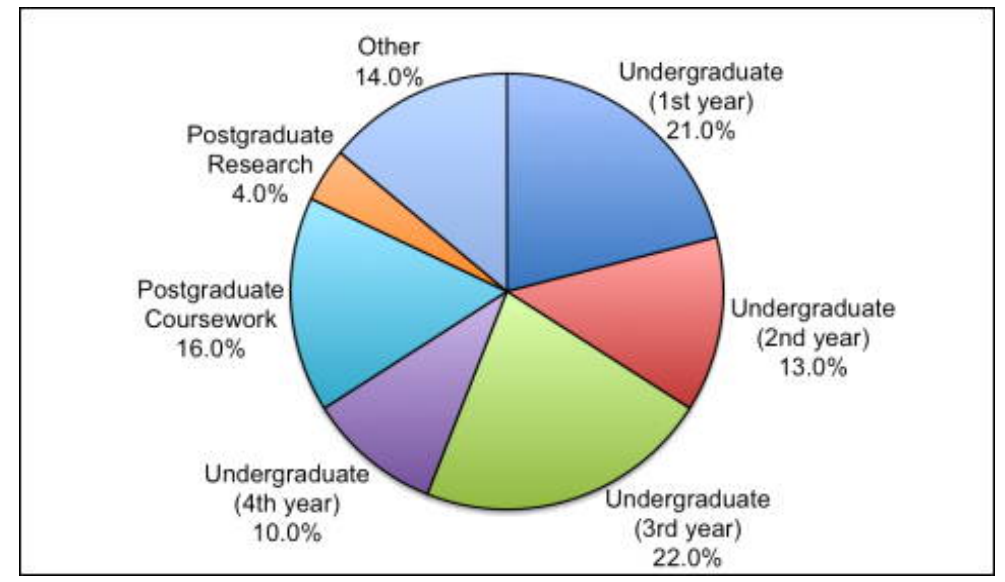

Figure 5: Subjects using 3D immersive virtual worlds by level

Figure 6 shows the subjects broken down by discipline area. Participants were asked to name in their own words the discipline area of each subject, and the responses were then coded into the following categories:

- Education;

- Arts and Humanities;

- Science;

- Health Professional;

- Information Technology / Computing;

- Legal and Business;

- Other.

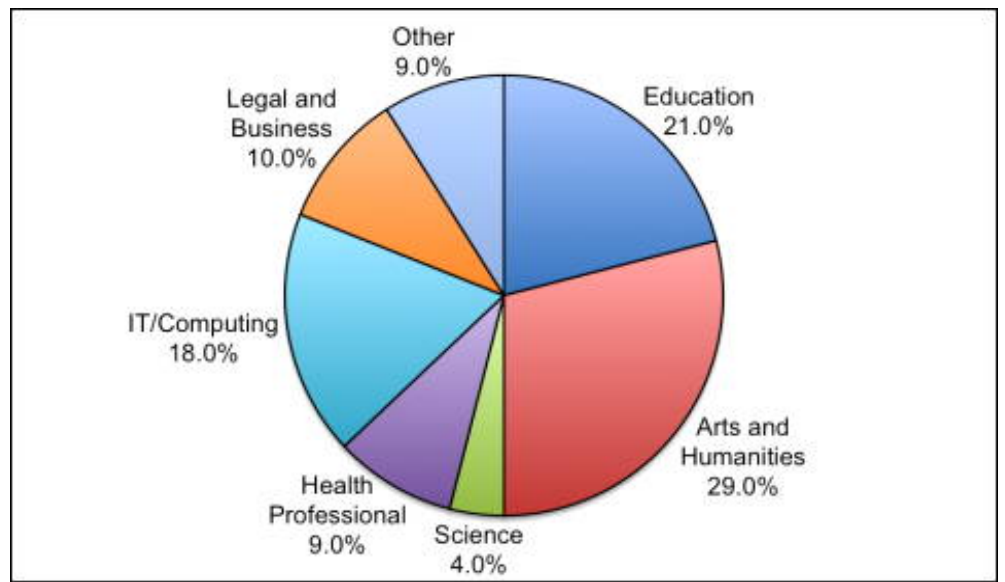

Figure 6: Subjects using 3D immersive virtual worlds by discipline area 


\section{Discussion}

The data presented in the previous section attest to the diversity of 3D immersive virtual world use in higher education across Australia and New Zealand in terms of the virtual world platforms used, the role of virtual world tasks in relation to assessment, as well as the delivery modes, levels and discipline areas of the subjects involved. In many ways, this diversity mirrors the findings of the JISC, Eduserv and ECAR reports cited earlier. It can also be seen from the questionnaire data that there has been a clear overall increase from year to year of subject offerings in which 3D immersive virtual worlds have been used over the past decade.

Second Life is by far the most popular 3D immersive virtual world platform, reported to have been used by $78 \%$ of the questionnaire respondents. In mid 2010, Linden Lab, the proprietor of Second Life, announced plans to dismiss one-third of its workforce (Linden Lab, 2010). Such occurrences, along with the demise of other competing platforms - such as that of There.com just a few months earlier (Wilson, 2010) - serve to underscore the risks of over-reliance or dependence on a specific platform. Educators should take steps to ensure that in the event their chosen platform ceases to be available, the resources they have developed will be able to be easily ported or transferred to other, alternative platforms. Hopefully, pedagogical and instructional design lessons learnt will also be readily transferrable. Interestingly, the Spring 2008 Eduserv report claimed that academics were not 'welded' to Second Life, "being aware of its deficiencies and open to moving to alternative virtual environments, especially open source and more localised versions" (Kirriemuir, 2008a, p. 2); subsequent reports in the series (e.g. Kirriemuir, 2009b, 2010) highlight the fact that while Second Life continues to be the most pervasive platform, staff and their institutions are increasingly looking toward alternatives like OpenSim and OLIVE (On-Line Interactive Virtual Environment) to meet their requirements. The results of the scoping study questionnaire also suggest that a noticeable proportion of higher education teaching staff and institutions across Australia and New Zealand are now developing custom or 'bespoke' virtual worlds and hosting them on their own servers and networks, willing to bear the higher costs and time commitment involved in exchange for greater levels of functionality, flexibility and control.

It is worth noting that $3 \mathrm{D}$ immersive virtual worlds and other desktop virtual reality environments have been in existence for over 20 years (de Freitas, 2008). They have been trialled and used in education long before the launch of Second Life in 2003, although the advent of the current generation of massively multi-user virtual worlds may have contributed to a resurgence of interest in the technologies and accelerated their uptake in education. Perhaps the learning affordances of these technologies (see Dalgarno \& Lee, 2010) are valuable enough so that they will outlast any particular software platform or system; meanwhile, research is required to understand the precise nature of these affordances and how they can be exploited in pedagogically sound ways. Furthermore, there is a need to make time for awareness raising, dialogue and professional development on what strategies, approaches, techniques and tools work best for achieving the desired learning outcomes, and to aid teaching staff in gaining the confidence and competence to integrate these successfully into their learning designs and teaching practices.

\section{Conclusion and next steps}

The substantial investments being made by higher education institutions and agencies in $3 \mathrm{D}$ immersive virtual worlds for learning and teaching call for large scale, sector- 
wide efforts that seek to capture and document staff members' perceptions and experiences relating to the use of the technology, and that attempt to identify good and/or best practices in the area. The Australian and New Zealand 3D immersive virtual worlds scoping study supported by DEHub set out to target this need through a systematic review and environmental analysis that parallels and complements studies conducted elsewhere, particularly the UK and USA.

This article has discussed the overall research design of the DEHub scoping study, in addition to presenting results drawn from the questionnaire phase of the study. Key points that have arisen are:

- Data are in general consistent with international findings (UK and USA);

- There has been a dramatic increase in the use of 3D immersive virtual worlds in Australian and New Zealand higher education institutions;

- There is a diversity of virtual worlds in use, although Second Life is the most popular platform;

- Uptake by academics is predominantly by more mature individuals aged 46 years and older;

- 3D immersive virtual worlds are being used largely in face to face or blended learning (as opposed to fully online/distance) scenarios, and mostly at an undergraduate level; and

- Half of the respondents were using the technology in the Arts, Humanities or Education disciplines.

The study will build on these results with further collection and analysis of quantitative and qualitative data related to higher education staff members' views and beliefs about 3D immersive virtual worlds for learning and teaching, their current and planned uses of the technology, and their observations and reflections on their experiences. In the final phase of the study, selected questionnaire respondents will be purposively sampled to participate in one on one interviews in order to allow for more in depth information and insights to be obtained. An important goal here will be to understand how the unique capabilities and affordances of 3D immersive virtual worlds are being exploited to deliver pedagogical benefits and outcomes in ways that would be difficult or impossible to achieve without the technology (see Dalgarno \& Lee, 2010).

The final project report, which is due for release in mid 2011, will include the complete results of the scoping study and incorporate a number of case studies of exemplary, innovative practice. These will be accompanied by an annotated bibliography of relevant publications and resources.

\section{References}

Atkinson, R. \& McBeath, C. (Eds) (2009). Same places, different spaces. Proceedings ascilite Auckland 2009. http: / / www.ascilite.org.au/conferences/ auckland09/ procs /

Bradshaw, D. (2006). Virtual worlds - real learning! Pedagogical reflections. Brisbane: Australian Flexible Learning Framework. http: / / virtualworlds.flexiblelearning.net.au/ reports/VWRL_pedagog_reflect.pdf

Campbell, M. (2009). Using 3D-virtual worlds to teach decision-making. In Same places, different spaces. Proceedings ascilite Auckland 2009. http:/ / www.ascilite.org.au/conferences / auckland09/procs/campbell-m.pdf

Collins, C. (2008). Looking to the future: Higher education in the Metaverse. EDUCAUSE Review, 43(5), 51-63. http:/ / www.educause.edu/ir/library/pdf/ERM0853.pdf 
Dalgarno, B. \& Lee, M. J. W. (2010). What are the learning affordances of 3-D virtual environments? British Journal of Educational Technology, 41(1), 10-32.

de Freitas, S. (2008). Serious virtual worlds: A scoping study. Bristol, UK: Joint Information Systems Committee. http:// www.jisc.ac.uk/media/documents/publications/seriousvirtualworldsv1.pdf

Gamage, V., Tretiakov, A. \& Crump, B. (2009). Educators' perceptions about using MUVE for teaching. In Same places, different spaces. Proceedings ascilite Auckland 2009. http:// www.ascilite.org.au/conferences/auckland09/procs/gamage-poster.pdf

Gregory, S., Lee, M. J. W., Ellis, A., Gregory, B., Wood, D., Hillier, M., Campbell, M., Grenfell, J., Pace, S., Farley, H., Thomas, A., Cram, A. Sinnappan, S., Smith, K., Hay, L., Kennedy-Clark, S., Warren, I., Grant, S., Craven, D., Dreher, H., Matthews, C., Murdoch, D. \& McKeown, L. (2010). Australian higher education institutions transforming the future of teaching and learning through 3D virtual worlds. In Curriculum, technology E transformation for an unknown future. Proceedings ascilite Sydney 2010. http: / / www.ascilite.org.au / conferences / sydney10 / Ascilite $\% 20$ conference $\% 20$ proceedings $\% 202010 /$ Gregory-full.pdf

Gregory, S. \& Tynan. B. (2009). Introducing Jass Easterman: My Second Life learning space. In Same places, different spaces. Proceedings ascilite Auckland 2009. http: / / www.ascilite.org.au/conferences/auckland09/procs/gregory.pdf

Henderson, M., Huang, H., Grant, S. \& Henderson, L. (2009). Language acquisition in Second Life: Improving self-efficacy beliefs. In Same places, different spaces. Proceedings ascilite Auckland 2009. http: / / www.ascilite.org.au/conferences/auckland09/procs/henderson.pdf

Hew, K. F. \& Cheung, W. S. (2010). Use of three-dimensional (3-D) immersive virtual worlds in K-12 and higher education settings: A review of the research. British Journal of Educational Technology, 41(1), 33-55.

Johnson, L., Levine, A. \& Smith, R. (2008). The Horizon Report: 2008 Australia-New Zealand edition. Austin, TX: New Media Consortium. http:/ / www.nmc.org/pdf/2008-Horizon-Report-ANZ.pdf

Kelton, A. J. (2007). Second Life: Reaching into the virtual world for real-world learning. Research Bulletin Volume 2007, Issue 17. Boulder, CO: EDUCAUSE Center for Applied Research. http: / / www.educause.edu/ir/library/pdf/ERB0717.pdf

Kennedy, G. E., Dalgarno, B., Bennett, S., Gray, K., Waycott, J., Judd, T., Bishop, A., Maton, K., Krause, K.-L. \& Chang, R. (2009). Educating the Net Generation: A handbook of findings for practice and policy. Melbourne: University of Melbourne Press.

Kirriemuir, J. (2007a). A July 2007 'snapshot' of UK higher and further education developments in Second Life. Bath, UK: Eduserv. [viewed 16 Dec 2010] http:/ / virtualworldwatch.net/wordpress / wp-content/uploads/2009/07/ snapshot-one.pdf

Kirriemuir, J. (2007b). An update of the July 2007 'snapshot' of UK higher and further education developments in Second Life. Bath, UK: Eduserv. [viewed 16 Dec 2010] http:/ / virtualworldwatch.net/wordpress / wp-content/ uploads/2009/07/ snapshot-two.pdf

Kirriemuir, J. (2008a). A Spring 2008 'snapshot' of UK higher and further education developments in Second Life. Bath, UK: Eduserv. http: / / virtualworldwatch.net/wordpress/wpcontent/uploads/2009/07/ snapshot-three.pdf [viewed 16 Dec 2010]

Kirriemuir, J. (2008b). The Autumn 2008 snapshot of UK higher and further education developments in Second Life. Bath, UK: Eduserv. [viewed 16 Dec 2010] http: / / virtualworldwatch.net/wordpress / wp-content/ uploads/2009/07/ snapshot-four.pdf

Kirriemuir, J. (2009a). Early Summer 2009 Virtual World Watch snapshot of virtual world activity in UK HE and FE. Bath, UK: Eduserv. [viewed 16 Dec 2010] http: / / virtualworldwatch.net/wordpress/wp-content/uploads/2009/06/ snapshot-six.pdf

Kirriemuir, J. (2009b). The Spring 2009 snapshot of virtual world use in UK higher and further education. Bath, UK: Eduserv. [viewed 16 Dec 2010] http: / / virtualworldwatch.net/wordpress / wp-content/uploads/2009/07/ snapshot-five.pdf

Kirriemuir, J. (2009c). Virtual world activity in UK universities and colleges: An academic year of expectation? Snapshot \# 7: Winter 2009. Bath, UK: Eduserv. [viewed 16 Dec 2010] http: / / virtualworldwatch.net/ wordpress / wp-content/ uploads/2009/12/Snapshot-7.pdf 
Kirriemuir, J. (2010). Virtual world activity in UK universities and colleges: Virtual teaching in uncertain times. Snapshot \#8: Spring 2010. Bath, UK: Eduserv. [viewed 16 Dec 2010] http:/ / virtualworldwatch.net/wordpress/wp-content/uploads/2010/05/Snapshot-8.pdf

Lee, M. J. W. (2009). How can 3D virtual worlds be used to support collaborative learning? An analysis of cases from the literature. Journal of e-Learning and Knowledge Society, 5(1), 149-158. http://www.je-lks.it/en/09_01/3met_lee_ing09.pdf

Lee, M. J. W. (2010). 3D immersive virtual worlds in higher education: Emerging academic staff and student perspectives on learning and teaching in new online spaces. Unpublished manuscript.

Linden Lab (2010). Linden Lab restructures to generate efficiencies and support investment in new platforms. http:/ / lindenlab.com/pressroom/releases/06_09_10 [viewed 28 Jun 2010]

New Media Consortium (2007). The Horizon Report: 2007 edition. Austin, TX: NMC. http:/ / www.nmc.org/pdf/2007_Horizon_Report.pdf

Oblinger, D. G. \& Oblinger, J. L. (Eds) (2005). Educating the Net Generation. Boulder, CO: EDUCAUSE. http: / / www.educause.edu/educatingthenetgen

Prensky, M. (2001a). Digital natives, digital immigrants. On the Horizon, 9(5), 1-6. http: / / www.marcprensky.com/writing/Prensky\%20-\%20Digital\%20Natives, $\% 20$ Digital\%20Immigrants\%20-\%20Part1.pdf

Prensky, M. (2001b). Digital natives, digital immigrants, Part II: Do they really think differently? On the Horizon, 9(6), 1-6. http: / / www.marcprensky.com/ writing/Prensky\%20$\%$ 20Digital\%20Natives,\%20Digital\%20Immigrants\%20-\%20Part2.pdf

Rogers, L. (2009). Simulating clinical experience: Exploring Second Life as a learning tool for nurse education. In Same places, different spaces. Proceedings ascilite Auckland 2009. http:/ / www.ascilite.org.au/conferences/auckland09/procs/rogers.pdf

Steel, C. H., Keppell, M. J., Gerbic, P. \& Housego, S. (Eds) (2010). Curriculum, technology E transformation for an unknown future. Proceedings ascilite Sydney 2010. http: / / www.ascilite.org.au/conferences / sydney10/ proceedings.htm

Willems, J. (2009). Different spaces but same places: Possibilities, pitfalls and persistent practices in Second Life. In Same places, different spaces. Proceedings ascilite Auckland 2009. http: / / www.ascilite.org.au/conferences/ auckland09/procs/willems.pdf

Willis, G. B. (1999). Cognitive interviewing: A 'how to' guide. Research Triangle Park, NC: Research Triangle Institute. [viewed 1 May 2010] http:// appliedresearch.cancer.gov/areas/cognitive/interview.pdf

Wilson, M. (2010). There.com closed on March 9th, 2010. [viewed 23 Apr 2010] http: / / www.there.com/info/announcement

This article is a revised and updated version of a paper that received an Outstanding Paper Award at ascilite Sydney 2010, gaining the additional recognition of publication in AJET. The reference for the Conference version is:

Dalgarno, B., Lee, M. J. W., Carlson, L., Gregory, S. \& Tynan, B. (2010). 3D immersive virtual worlds in higher education: An Australian and New Zealand scoping study. In Curriculum, technology E transformation for an unknown future. Proceedings ascilite Sydney 2010. http:/ / www.ascilite.org.au/conferences/ sydney10/ Ascilite\%20conference\%20proceedings\%202010/Dalgarno-full.pdf

Authors: Barney Dalgarno, School of Education, Charles Sturt University, Locked Bag 588, Wagga Wagga, NSW 2678, Australia. Email: bdalgarno@csu.edu.au

Barney is an Associate Professor of Educational Technology in the School of Education at Charles Sturt University. His research interests include the educational affordances of 3D virtual learning environments, the application of constructivist theories to technology facilitated learning design, critical exploration of the impact of 
generational changes on learners, learning and learning technologies and the use of functional brain imaging to explore interactivity and cognition. As well as being awarded a number of research and teaching grants, he has received national recognition through awards for innovative teaching and learning design using leading-edge technologies.

Mark J. W. Lee, School of Education, Charles Sturt University, Locked Bag 588, Wagga Wagga, NSW 2678, Australia. Email: malee@csu.edu.au

Mark is an Adjunct Senior Lecturer with the School of Education at Charles Sturt University. He also concurrently serves as Adjunct Senior Lecturer with the DEHub research institute at the University of New England, as well as Honorary Research Fellow with the Graduate School of IT and Mathematical Sciences at the University of Ballarat. Mark has published widely in the fields of educational technology, e-learning and innovative pedagogy in higher education, with over 50 refereed publications to his name. His current research interests include pedagogical uses of Web 2.0, mobile learning, digital game-based learning and the use of 3D virtual environments for learning, as well as the beliefs and practices of academic staff.

Lauren Carlson School of Education, Charles Sturt University, Locked Bag 588, Wagga Wagga, NSW 2678, Australia. Email: lcarlson@csu.edu.au

Lauren Carlson is a Research Assistant with the School of Education at Charles Sturt University, and with the Research Institute for Professional Practice, Learning and Education (RIPPLE) at the same university. She is currently involved in research projects in the areas of mathematics education and the use of 3D virtual worlds for tertiary teaching and learning. Lauren holds a Bachelor of Education (Primary) from CSU, in which she graduated with first class honours.

Sue Gregory, DEHub and School of Education, Faculty of The Professions, University of New England, Armidale, NSW 2351, Australia. Email: sue.gregory@une.edu.au Sue is a Lecturer in ICT in the School of Education as well as a Research Fellow with the DEHub research institute at the University of New England and Chair of the DEHub Virtual Worlds Working Group. She is responsible for training pre-service and postgraduate education students on how to incorporate technology into their teaching. Since 2007, through her avatar, Jass Easterman, she has been researching Second Life with her students with respect to the various learning opportunities that virtual worlds provide, and has been involved in many projects on the efficacy of virtual worlds.

Belinda Tynan, DEHub, Faculty of The Professions, University of New England, Armidale, NSW 2351, Australia. Email: belinda.tynan@une.edu.au

Belinda is a Professor and Academic Director in the Faculty of the Professions at the University of New England, and also Director of the DEHub research institute.

Additionally, she directs Project 2012, the University's strategic initiative on flexible and online learning. Belinda has held numerous teaching positions in the UK, Australia and Japan, and has demonstrated experience in the management of large projects in the higher education sector, both in Australia and overseas. Her research covers a range of areas such as music teaching, distance education, academic staff development and collaboration.

Please cite as: Dalgarno, B., Lee, M. J. W., Carlson, L., Gregory, S. \& Tynan, B. (2011). An Australian and New Zealand scoping study on the use of 3D immersive virtual worlds in higher education. Australasian Journal of Educational Technology, 27(1), 1-15. http: / / www.ascilite.org.au/ajet/ajet27/dalgarno.html 